\title{
O COMPLEXO MÁFICO-ULTRAMÁFICO DE CANA BRAVA, GO: ASPECTOS PETROLÓGICOS E ESTRATIGRÁFICOS
}

\author{
C.T.Correia ${ }^{1}$
}

O Complexo máfico-ultramáfico de Cana Brava situa-se a aproximadamente 300 km ao norte de Brasília no Estado de Goiás.

As principais unidades geológicas da região correspondem ao Grupo Serra da Mesa (MARINI et al., 1977), à seqüência vulcano-sedimentar de Palmeirópolis (RIBEIRO FILHO \& TEIXEIRA, 1981) e ao próprio complexo.

Segundo GIRARDI et al. (1982), as rochas do complexo compreendem metagabros, metagabronoritos, metanoritos, anfibolitos, metapiroxenitos e serpentinitos, sendo as rochas máficas dominantes em relação às ultramáficas. Quanto à sua gênese, MARINI et al. (1977) sugerem seja classificado como um maciço do tipo alpino. DANNI et al. (1982) o inclui em uma faixa móvel granulítica do Proterozóico Inferior que se estenderia do norte de Goiás até o oeste de Minas Gerais, enquanto que GIRARDI et al. (1982) consideram que corresponda a um corpo magmático intrusivo diferenciado que foi soerguido por falhamentos em bloco. Tal hipótese é corroborada pelo trabalho de FUGI (1989) que conclui, com base no padrão das terras raras das rochas do Complexo, que este parece ter sido formado em uma câmara magmát ${ }^{i}$ ca por cristalização fracionada de um magma basáltico original enriquecido em terras raras leves. Quanto à geocronologia, FUGI (1989) apresenta a idade isocrônica Sm-Nd de $1970 \pm 69 \mathrm{Ma}$. para o Complexo. Considera que este dado é coerente com a isócrona $\mathrm{K}-\mathrm{Ar}$ de 1925 $\pm 110 \mathrm{Ma}$. obtida por GIRARDI et al. (1978), e a interpreta como a idade de cristalização do Complexo. Explica as idades $\mathrm{K}-\mathrm{Ar}$ e $\mathrm{Rb}-\mathrm{Sr}$ mais recentes como efeito de rejuvenescimento posteriores ao ciclo tectonotermal Transamazônico ao qual estaria relacionado.

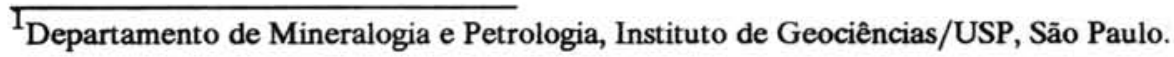


A oeste do Complexo de Cana Brava,ocupando a porção central da região em foco,encontra-se a seqüência vulcano-sedimentar de Palmeirópolis, conforme definida por RIBEIRO FILHO \& TEIXEIRA (1981). Anteriormente, a área de exposição de suas rochas só tinha referências no projeto Brasília (BARBOSA et al., 1969) que relacionava todos os anfibolitos e xistos situados a oeste do Complexo de Cana Brava como pertencentes ao vulcanismo básico inicial do Grupo Araxá. Trabalhos posteriores como o projeto Palmeirópolis (LEÃO NETO et al., 1983) têm abribuído a estas rochas idade proterozóica inferior, estando elas sotopostas por discordância ao grupo Serra da Mesa. Neste sentido a isócrona Rb-Sr de $1157 \pm 50 \mathrm{Ma}$. de GIRARDI et al. (1978) tem sido interpretada como referente à idade do metamorfismo principal da seqüência. MARQUES \& MARQUES (1985) tratam a seqüência como parte de um cinturão vulcano-sedimentar tipo faixa móvel ensimático, sobreposto ao Complexo de Cana Brava, com o qual afirmam apresentar relações estratigráficas complexas. Adotam a subdivisẫo estratigráfica para a seqüência proposta por FIGUEIREDO et al. (1981) que a subdividem em uma subunidade anfibolítica, outra xistosa e no granito intrusivo do Morro Solto. Neste trabalho apresentam abundantes dados geoquímicos destas rochas e das mineralizações de $\mathrm{Cu}, \mathrm{Zn}$, e $\mathrm{Pb}$ nelas existentes, e a partir deles concluem que suas rochas correspondem principalmente a toleítos espilitizados e rochas vulcânicas oceânicas ácidas e intermediárias.

Segundo MARINI et al. (1977) as rochas do Grupo Serra da Mesa afloram na região junto à borda $\mathrm{E}$ do Complexo de Cana Brava e ao redor dos granitos Serra Dourada, Serra da Mesa e Serra Branca. Encontram-se representadas por mica xistos, quartzitos, anfibolitos e paragnaisses, anteriormente relacionados ao Grupo Araxá.

Em relação às unidades anteriormente referidas permanecem dúbios vários aspectos. Não é consenso entre os autores as relações entre o complexo e a seqüência vulcanosedimentar de Palmeirópolis. Enquanto na maioria dos mapas existentes o contato a oeste seja desenhado como tectônico, observações de campo não mostram evidências de cataclase, quer nas rochas do complexo, quer nos xistos da seqüência de Palmeirópolis a elas adjacentes. Por outro lado, próximos ao contato existem afloramentos com xenólitos de xistos, quartzitos e anfibolitos nos gabros e dioritos do complexo, indicando caráter magmático para este contato. Igualmente não está definido se o conjunto de rochas anfibolíticas cisalhadas que se encontram no limite este do Complexo correspondem à unidade basal do mesmo, conforme sugerem MATSUI et al. (1976), GIRARDI et al. (1982) e FUGI (1989), ou pertencem à seqüência vulcano-sedimenar de Palmeirópolis, como indicado nos trabalhos de MARQUES \& MARQUES (1985) e LEÃO NETO et al. (1986). 
Neste sentido estamos procedendo a novas análises geocronológicas e a mais de cem análises geoquímicas para elementos maiores e menores dos principais litotipos da área que permitirão melhor definir sua estratigrafia e os processos petrológicos emos processos petrológicos envolvidos na sua formação.

\section{REFERÊNCIAS BIBLIOGRÁFICAS}

BARBOSA, O.; BAPTISTA, M.B.; DYER, R.C.; BRAUN, O.P.G.; COSTA, J.C. (1969) Geologia e inventário dos recursos minerais de Projeto Brasília. PROSPEC/DNPM. PETRÓPOLIS (inédito).

DANNI, J.C.M.; FUCK, R.A.; LEONARDOS, O.H. (1982) Archean and Lower Proterozoic units in Central Brasil. Geologische Rundschau, 71(1):291-317.

FUGI, M.Y. (1989) REE geochemistry and Sm/Nd geocronology of the Cana Brava complex Brazil. Kobe, 55p. (Master-Thesis University of Kobe Dep. of Earth Science).

GIRARDI, V.A.V.; KAWASHITA, K.; BASEI, M.A.S.; CORDANI, U.G. (1978) Algumas considerações sobre a evolução geológica da regiẫo de Cana Brava, a partir de dados geocronológicos. In: CONGRESSO BRASILEIRO DE GEOLOGIA, 30., Recife, 1978. Anais. Recife, SBG. V.1, p.337-348.

GIRARDI, V.A.V. \& KURAT, G. (1982) Precambrian mafic and ultramafic rocks of the Cana Brava Complex, Brazil. Mineral compositions and evolution. Revista Brasileira de Geociências, 12(1-3):313-323.

LEÃo NEto, R. \& OLIVATti, O. (1983) Projeto Palmeirópolis - Etapa preliminar. Convênio DNPM-CPRM, Goiânia, 29p., mapa anexo, inédito.

LEÃO NETO, R.; OLIVEIRA, I.W.B.; DRAGO, V.A. (1986) Aspectos da geologia, evolução e mineralizações da seqüência vulcano-sedimentar de Palmeirópolis. In: CONGRESSO BRASILEIRO DE GEOLOGIA, 34., Goiânia. Roteiro das excursões técnico-científicas. Boletim, 2. Goiânia, SBG. p.7-24. 
MARINI, O.J.; FUCK, R.A.; DARDENNE, M.A.; FARIA, A. de (1977) Contribuição à geologia do Pré-cambriano da porção central de Goiás. Revista Brasileira de Geociências, 7(4):304-324.

MARQUES, V.J. \& MARQUES, M.T.G. (1985) Ambiência geológica-geotectônica da seqüência vulcano-sedimentar de Palmeirópolis (GO) - guias e controle das mineralizações. In: SIMPÓSIO DE GEOLOGIA DO CENTRO-OESTE, 2., Goiânia, 1985, Anais. Goiânia, SBG. p.208-324.

MATSUI, K.; GIRARDI, V.A.V.; BASEI, M.A.S.; HASUI, Y. (1976) Idades do complexo básico-ultrabásico de Cana Brava, Goiás. In: CONGRESSO BRASILEIRO DE GEOLOGIA DO CENTRO-OESTE, 2., Goiânia, 1985, Anais. Ouro Preto, SBG. V.4, p.269-277.

RIBEIRO FILHO, E. \& TEIXEIRA, N.A. (1981) Seqüência vulcano-sedimentar da borda oeste dos complexos de Niquelândia e Cana Brava. Boletim Informativo. Núcleo CentroOeste, 10:157-177. 